\title{
Prevention of Hepatocellular Carcinoma: Vaccination and Dietary Changes Show Promise to Eliminate Most Cases of Human Liver Cancer
}

\section{Stewart Sell*}

New York State Health Department, Wadsworth Center, Albany College of Pharmacy and University at Albany, USA

\section{Introduction}

Hepatocellular Carcinoma (HCC) is the $5^{\text {th }}$ or $6^{\text {th }}$ most common cancer worldwide. It has a poor prognosis, with the number of cases $(626,000)$ closely resembling the number of deaths $(598,000)$ making it the $3^{\text {rd }}$ leading cause of cancer-related deaths in the world [1,2]. In the US, HCC is the $6^{\text {th }}$ highest cause of cancer death in men and $9^{\text {th }}$ highest in women. It has the second lowest 5 year survival rate $(11.7 \%)$ of all cancers and its incidence shows a steady increase since 1980 [3]. Most cases of HCC occur in south-east Asia and sub-Saharan Africa, where dietary exposure to aflatoxin (AFB1), along with chronic hepatitis infection, are the most important risk factors [4-21]. Either AFB1 exposure or Hepatitis B Virus (HBV) carrier status alone increases the relative risk of developing HCC up to 17; when present together, the risk increases to between 60 and 70 [22-25]. The incidence of HCC in low and middle income countries is much higher than that of high income countries [26]. However, low levels of AFB1 contamination is widespread in the United States and may play a role in the etiology of HCC in the U. S $[27,28]$. Upon ingestion, AFB1 is activated by cytochrome P-450-mediated oxidation to mutagenic AFB1-8,9-exoepoxide (AFBO) [29,30]. AFBO binds to DNA, forms AFB1-N ${ }^{7}$ guanine adducts and produces mutations, including those observed in the p53 gene [31,32]. Protection against adduct formation occurs by detoxification of AFBO, principally by GST-mediated conjugation of AFBO with reduced glutathione (GSH) [29]. Unfortunately, humans do not have an effective GST detoxification subtype as does the adult mouse. HCCs associated with AFB1 and HBV have a high frequency of mutations in the p53 at codon 249 [9-11]. How binding of the AFB1 epoxide to DNA may cause this mutation is not known.

\section{Prevention}

Two risk factors are responsible for the high incidence of HCC in resource-poor countries: dietary exposure to AFB1 and chronic HBV infection. The increasing incidence of HCC in Western countries is associated with $\mathrm{HBV}$ or Hepatitis C (HCV) infection. Global prevention of Hepatocellular Carcinoma (HCC) has become a possibility through elimination of aflatoxin exposure, immunization against hepatitis $\mathrm{B}$ [33-35] and control of Hepatitis C Virus (HCV) infection. However, each of these measures is costly and requires considerable public health efforts and liaison among healthcare providers and policy makers, as well as development of cost effective strategies applicable to local situations [26].

\section{Aflatoxin exposure}

Only 7 or 8 years ago acute aflatoxin exposure caused over 150 deaths in Kenya [33]. Almost 30 years ago, Sun [15,16] documented the relationship between the source of water consumption and HCC in high incidence areas of China. This is because of the method of "curing" a major food product that is used in high-incidence areas of both China and Africa. The crop is "ground nuts" which are harvested in the form of entire plants, which are placed on the roof of houses to "cure" in the sun. High humidity in these areas promotes growth of Aspergillus flavus, a mould that produces high amounts of aflatoxin [29]. Use of water collected from the roofs covered with moldy plants into rain barrels is associated with the highest incidence of HCC $[15,16]$; HCC incidence in next highest when ditch water from the fields is used. This is followed in order by use of river water and then well water (Figure 1). Since 1973, The Chinese government has been urging farming communities to drink only deep well water [16]. In Wuidong province, $80 \%$ of the population now drinks primarily well water as compared to only $20 \%$ previously. The workshop report of the Centers for Disease Control and Prevention and the World Health Organization produced a detailed report on what else should be done [33]. Steps are now directed toward managing the horticulture of the ground nut crop, including timing of planting, genotype of seeds used, irrigation, use of insecticides, timing of the harvest, how crop is dried and stored to prevent mould growth and treatment of the nuts after harvesting to decontaminate or inactivate the aflatoxin [36-38]. For example, pre-harvest practices such as proper irrigation or treatment with fungicides could be very effective and post harvest prevention of contamination may be accomplished by simple approaches such as drying the crops on cloth rather than on roofs or dirt, hand sorting to remove moldy plants, and storage in cold-dry places [38]. In one small area of China, reduction in aflatoxin exposure was achieved

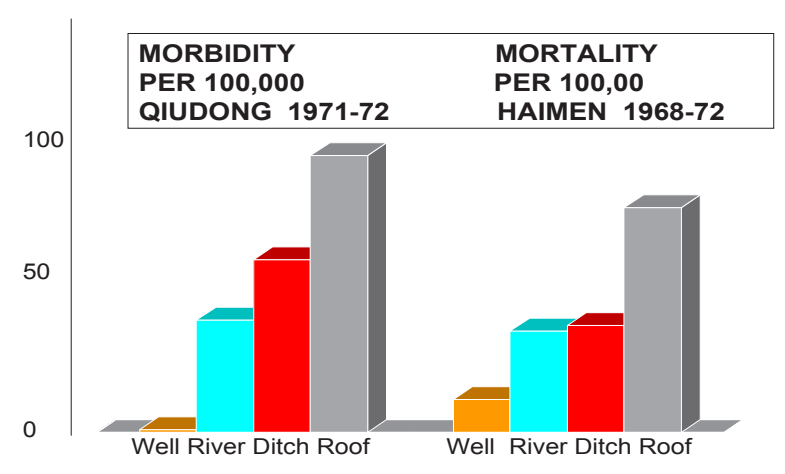

Figure 1: Relationship of rate of liver cancer incidence and death to source of drinking water [74].

${ }^{*}$ Corresponding author: Stewart Sell, New York State Health Department Wadsworth Center, Albany College of Pharmacy and University at Albany, P. O. Box 509, Room C-405, Empire State Plaza, Albany, NY 12201, USA, Tel: 518408-1001; Fax: 518-473-2900/518-402-5381; E-mail: ssell@wadsworth.org

Received November 16, 2012; Accepted November 19, 2012; Published November 26, 2012

Citation: Sell S (2012) Prevention of Hepatocellular Carcinoma: Vaccination and Dietary Changes Show Promise to Eliminate Most Cases of Human Liver Cancer. J Carcinogene Mutagene 3:e108. doi:10.4172/2157-2518.1000e108

Copyright: ( 2012 Sell S. This is an open-access article distributed under the terms of the Creative Commons Attribution License, which permits unrestricted use, distribution, and reproduction in any medium, provided the original author and source are credited. 
by switching from an A. flavus susceptible crop to a less susceptible crop: i.e., by a change from a ground nut based crop to rice [38]. It is recommended that this approach be combined with monitoring the food crop for aflatoxin contamination [34]. For example, monitoring of food products in Brazil revealed AFB1 contamination in $8.1 \%$ in peanuts and $6 \%$ in Brazil nuts [39]. Although the level of exposure was low and its effect problematical, continued surveillance of food products was recommended to try to reduce this exposure. Effective removal of contaminated foods, combined with selection of crops and use of optimal drying and storage practices, can essentially eliminate harmful exposure in developing countries [36,37]. However, developing countries may lack the resources and technologies required, as well as the infrastructure to effectively limit exposure. With rapid economic development this situation should not last much longer.

\section{Hepatitis B (HBV)}

Vaccination against HBV infection protects against chronic liver disease which is a major risk factor for HCC $[38,40]$. In high risk HCC areas of the world up to $15 \%$ of individuals are chronically infected with HBV and up to $25 \%$ of these will develop HCC [41]. In these areas $\mathrm{HBV}$ infection almost always occurs in infancy either by passage from the mother during pregnancy or perinatally. Thus, to be effective any vaccination procedure needs to be directed to the mother or be administered neonatally. Ninety percent of those infected within the first year of life will develop chronic liver disease and eventually HCC [6]. Introduction of a vaccination program in Taiwan for all preschool children in 1984 has resulted in a marked decrease in the number of babies born to infected mothers and a 10 fold decrease in the rate of chronic HBV infection [42]. The occurrence of HCC among vaccines has already decreased by $70 \%$ as compared to non-vaccinated cohorts [43].

Because HBV vaccination should be administered neonatally to be most effective, it is advisable to administer Hyperimmune Globulin (HBIG) along with the vaccination [41]. This is because the infant's immune system may not be able to respond to the early vaccination. By administering HBIG, passive antibodies are able to check early virus infection until the recipients immune system can respond to the vaccine. Unfortunately, the expense of HBIG poses a problem for applying effective vaccination programs in developing countries. For programs now underway, it will take up to 30-50 years to determine how effective vaccination will be in reducing HCC. This is because there is at least a 20-30 year lag time between chronic liver injury and development of HCC [40]. For example a vaccination program in Gambia (West Africa) has shown $84 \%$ protection against HBV infection and $94 \%$ against chronic HBV carrier rates at 9 years of age [44]. However, because of the lag time mentioned above it will not be possible to evaluate the effectiveness on prevention of HCC until 2017 [45]. HBV vaccination has been recommended for all neonates in China since 1992 with essentially 100\% coverage in Beijing being accomplished. The HBsAg carrier rate in the general population decreased to $7.2 \%$ in 2006 [46] and the prevalence of HBsAg decreased to $2.3 \%$ in children aged 5-14 years and to $1.0 \%$ among children younger than 5 years. Unfortunately even after administration of HBV immunogllbulin and $\mathrm{HBV}$ vaccine to children with $\mathrm{HBs} A \mathrm{~g}$ mothers the failure rate of $\mathrm{HBV}$ vaccination was $5-10 \%$ [46]. This failure is believed to be due to HBV $\mathrm{S}$ gene mutations and inadequate administration of the vaccine. In addition, the combined effect of vaccination and control of aflatoxin exposure has not been fully considered in these studies [47].
In chronically infected patients effective antiviral treatment using interferon or nucleoside analogues can delay disease progression to cirrhosis of HCC. A persistent high HBV DNA level is an accurate predictor for disease progression. Infected patients can be followed using ultrasonography and serum alpha fetoprotein every 3 months for early detection of HCC [48]. Early detection is critical to effective surgical treatment. Adjuvant interferon treatments may help prevent recurrence and nucleoside analogs may prevent do novo tumor development in the liver remnant by suppressing viral replication.

\section{Hepatitis C}

Unfortunately, despite considerable effort, there is no effective vaccine for hepatitis $\mathrm{C}(\mathrm{HCV})$. The most effective approach to prevention of HCV are public health measures such as avoidance of high risk behavior (injected drug use) and promiscuous sexual activity [40]. In particular, only sterilized syringes and needles should be used and syringes should be disposed of after a single use. Chronically infected individuals should be identified and urged to try to avoid circumstances where infection might be transmitted. Non-infected individuals engaging in at risk behavior should received counseling. In any case, hepatitis $\mathrm{C}$ is an increasing public health hazard in the Western World.

\section{Alcohol}

In the United States and Europe, with a relatively low incidence of viral hepatitis, heavy ethanol consumption is also considered a major risk factor [49]. Only 9\% of HCCs in the US are attributable to $\mathrm{HCV}$ and $20 \%$ to HBV [50]. The contribution of aflatoxin exposure to HCCs in the United States is not clearly known, but it is suspected that trace exposure to aflatoxin may synergize with alcohol injury and viral hepatitis as a critical risk factor for HCC $[51,52]$. Chronic ethanol intake causes chronic liver disease in humans, which progresses from early injury/steatosis, through hepatitis (fibrosis) to cirrhosis. The association of the late stages of cirrhosis with HCC has led most investigators to consider cirrhosis as a major risk factor for HCC [53-55]. However, there is actually a negative association between ethanol consumption and the risk of HCC in cirrhotic patients [56]. In addition, only one in 12 alcoholi cs develops cirrhosis [57] and only 5-10\% of patients with cirrhosis develop HCC [58,59]. Although liver cirrhosis and development of HCC is associated with chronic alcoholism in humans, the majority of alcoholics do not develop cirrhosis and the percentage of alcoholics that develop HCC is low [60]. Probably not more than $10 \%$ of chronic alcoholics develop cirrhosis after prolonged chronic alcohol ingestion. In a series of 200 patients with chronic alcohol consumption periportal lymphocytic infiltration was identified in only $40 \%$ [61] and in a study of 268 patients with long term alcoholism, 151 had no significant fibrosis [62]. There findings suggest that risk factors other than cirrhosis determine which alcoholics will develop alcoholic hepatitis and HCC. It is clear that patients with a history of hepatitis $\mathrm{B}$ or $\mathrm{C}$ should limit alcohol intake, but it is not clear just how much restricting alcohol consumption would reduce the incidence of HCC.

\section{Summary}

Current application of universal vaccination against hepatitis B and institution of effective measures to prevent aflatoxin contamination of grains should result is a massive reduction in the number of patients developing liver cancer in high incidence areas of the world within the next 20 years. A reduction should also become evident in lower incidence areas of the world, such as the US, but the effect is expected to be much less and more difficult to evaluate. 
Citation: Sell S (2012) Prevention of Hepatocellular Carcinoma: Vaccination and Dietary Changes Show Promise to Eliminate Most Cases of Human Liver Cancer. J Carcinogene Mutagene 3:e108. doi:10.4172/2157-2518.1000e108

\section{Papilloma virus}

Vaccination against hepatitis B may be considered the first and so far the most effective vaccine to reduce incidence of a cancer, but not the only one, as vaccination against Human Papilloma Viruses (HPVs) also promises to have a major impact on cervical cancer [63]. The vaccines now used for HPVs are directed to two major HPV types $[16,18]$ and vaccination using this vaccine is projected to reduce human cervical cancer by $70 \%$ in the next 20 years [64,65]. Expansion of the vaccine to additional types $[31,33,45,52,58]$ could reduce cervical cancer even more, up to $90 \%$ [63]. In addition, vaccination against Epstein-Barr Virus (EBV) for prevention of Burkitt lymphoma and against Human T-Cell Leukemia/Lymphoma Virus (HTLV) have been proposed [66] but to date there are no prospects of vaccines for these [67].

\section{Smoking}

Despite these considerable accomplishments in cancer prevention, they pale in the face of the impact of smoking on lung cancer, cancer of the larynx, oral cavity, pharynx, esophagus, stomach, pancreas, liver, kidney bladder, uterine cervix and bone marrow, as well as colon, rectum and ovary $[68,69]$. Tobacco use is by far the largest single cause of premature death in the developed world accounting for up to $21 \%$ of deaths among men and $17 \%$ among women [70]. Although there are other hazards such as radon and occupational exposures, the vast majority of lung cancer deaths are attributable to cigarette smoking $[71,72]$. Although it is projected that smoking prevalence and smokingattributed mortality will decrease in most developed countries [73], the rate of increased smoking in developing countries appears to be increasing as economic conditions improve. In any case, whereas major accomplishments in reduction of liver and cervical cancer have been made through vaccination, much more could be accomplished in cancer prevention by smoking reduction than by any other approach known at this time.

\section{References}

1. Bartlett DL, Di Bisceglie AM, Dawson LA (2008) Cancer of the liver, Cancer. Principles \& Practice of Oncology, 8th edition. Lippincott Williams \& Wilkins, New York.

2. Gomaa AI, Khan SA, Toledano MB, Waked I, Taylor-Robinson SD (2008) Hepatocellular carcinoma: epidemiology risk factors and pathogenesis. World J Gastroenterol 14: 4300-4308.

3. American Cancer Society (2009) Cancer Facts and Figures 2009.

4. Sell S (2003) Mouse models to study the interaction of risk factors for human liver cancer. Cancer Res 63: 7553-7562.

5. Munoz N, Bosch F (1987) Epidemiology of Hepatocellular Carcinoma Neoplasms of the Liver. K. Okuda and K. Ishak, edition, Springer-Verlag, Tokyo, Japan.

6. Beasley RP, Hwang LY, Lin CC, Chien CS (1981) Hepatocellular carcinoma and hepatitis B virus. A prospective study of 22,707 men in Taiwan. Lancet 2: 1129-1133.

7. Su D (1979) Drinking water and liver cell cancer. An epidemiologic approach to the etiology of this disease in China. Chin Med J 92: 748-756.

8. Yeh FS, Yu MC, Mo CC, Luo S, Tong MJ, et al. (1989) Hepatitis B Virus, aflatoxin and hepatocellular carcinoma in Southern Guangxi, China. Cancer Res 49: 2506-2509.

9. Ozturk M (1991) p53 mutation in hepatocellular carcinoma after Aflatoxin B1 exposure. Lancet 338: 1356-1359.

10. Bressac B, Kew M, Wands J, Ozturk M (1991) Selective G to T mutations of p53 gene in hepatocellular carcinoma from Southern Africa. Nature 350: 429-431.

11. Hollstein M, Sidransky D, Volgestein B, Harris CC (1991) p53 mutations in human cancers. Science 253: 49-53.
12. Van Rensburg SJ, Cook-Mozaffari P, Van Schalkwyk DJ, Van der Watt JJ, Vincent TJ, et al. (1985) Hepatocellular carcinoma and dietary aflatoxin in Mozambique and Transkei. Br J Cancer 51: 713-726.

13. Yu SZ (1989) Epidemiology of primary liver cancer. Subclinical Hepatocellular Carcinoma, Tang ZY edition, Springer-Verlag, Berlin, Germany.

14. Aguilar F, Harris CC, Sun T, Hollstein M, Cerutti P (1994) Geographic variation of p53 mutational profile in non malignant human liver. Science 264: 1317-1319.

15. Sun TT, Chu YY (1984) Carcinogenesis and prevention strategy of liver cancer in areas of prevalence. J Cell Physiol 3: 39-44.

16. Sun TT, Wu SM, Wu YY, Chu YR (1986) Measurement of individual aflatoxin exposure among people having different risk for primary hepatocellular carcinoma. Princess Takamatsu Symp 16: 225-235.

17. Li KC, Li HP, Wong SS, Chuang YS (1977) Survey of aflatoxin contaminations in peanuts from various areas in Taiwan. Taichung: Taiwan Agricultural Chemical and Toxin Substances Research Institute, Taiwan.

18. Chen CJ, Wang LY, Lu SN, Wu MH, You SL, et al. (1996) Elevated aflatoxin exposure and increased risk of hepatocellular carcinoma. Hepatology 24: 3842.

19. Tabor $E$ (1991) Strongly supported features of the association between hepatitis $B$ virus and hepatocellular carcinoma. Etiology, Pathology and Treatment of Hepatocellular Carcinoma in North America, Tabor E, Bisulgi AM, Purcell RH edition, The Woodlands, Texas, USA.

20. Groopman JD, Kensler TW (2005) Role of metabolism and viruses in aflatoxininduced liver cancer. Toxicol Appl Pharmacol 206: 131-137.

21. Wild CP, Montesano R (2009) A model of interaction: aflatoxins and hepatitis viruses in liver cancer etiology and prevention. Cancer Lett 286: 22-28.

22. Ross RK, Yuan JM, Yu MC, Wogan GN, Qian GS, et al. (1992) Urinary aflatoxin biomarkers and risk of HCC. Lancet 339: 943-946.

23. Qian GS, Ross RK, Yu MC, Yuan JM, Gao YT, et al. (1994) A follow-up study of urinary markers of aflatoxin exposure and liver cancer risk in Shanghai, PR China. Cancer Epidemiol Biomarkers Prev 3: 3-10.

24. Wang LY, Hatch M, Chen CJ, Levin B, You SL, et al. (1996) Aflatoxin exposure and risk of HCC in Taiwan. Int J Cancer 67: 620-625.

25. Lunn RM, Zhang YJ, Wang LY, Chen CJ, Lee PH, et al. (1997) P53 mutations, chronic hepatitis B infection and aflatoxin exposure in HCC in Taiwan. Cancer Res 57: 3471-3477.

26. Wong VW, Chan HL (2012) Prevention of hepatocellular carcinoma: a concise review of contemporary issue. Ann Hepatol 11: 284-293.

27. Abbas HK, Wilkinson JR, Zablotowicz RM, Accinelli C, Abel CA, et al (2009) Ecology of Aspergillus flavus, regulation of aflatoxin production and management strategies to reduce aflatoxin contamination of corn. Toxin Reviews 28: 142-153.

28. Hoque A, Patt YZ, Yoffe B, Groopman JD, Greenblatt MS, et al. (1999) Does aflatoxin B1 play a role in the etiology of hepatocellular carcinoma. Nutr Cancer 35: 27-33.

29. Eaton DL, Ramsdell HS, Neal GE (1994) Biotransformation of Aflatoxin B1. In: The Toxicology of Aflatoxin: Human Health, Veterinary and Agricultura Significance. DL Eaton, JD Groopman, edition, Academic, New York.

30. Gorelick NJ (1990) Risk assesments for aflatoxin B1. I. Metabolism of aflatoxin B1 by different species. Risk Anal 10: 539-559.

31. Bressac B, Kew M, Wands K, Ozturk M (1991) Selective G to T mutations of p53 gene in hepatocellular carcinoma from southern Africa. Nature 350: 429431.

32. Hsu IC, Metcalf RA, Sun T, Welsh JA, Wang NJ, et al. (1991) Mutational hotspots in the p53 gene in human hepatocellular carcinomas. Nature 350 : 427-428.

33. Strosnider H, Azziz-Baumgartner E, Banziger M, Bhat RV, Breiman R, et al (2006) Workshop report: public health strategies for reducing aflatoxin exposure in developing countries. Environ Health Perspectives 114: 1898-1903.

34. Turner PC, Sylla A, Gong YY, Diallo MS, Sutcliffe AE, et al. (2005) Reduction 
Citation: Sell S (2012) Prevention of Hepatocellular Carcinoma: Vaccination and Dietary Changes Show Promise to Eliminate Most Cases of Human Liver Cancer. J Carcinogene Mutagene 3:e108. doi:10.4172/2157-2518.1000e108

in exposure to carcinogenic alflatoxins by post harvest intervention measures in West Africa: a community-based intervention study. Lancet 11: 7953-7957.

35. Sudakin KI (2003) Dietary aflatoxin exposure and chemoprevention of cancer: a clinical review. J Toxicol Clin Toxicol 41: 195-204.

36. Phillips RD, Clement BA, Park DL (1994) Approaches to reduction of aflatoxins in foods and feeds. The Toxicology of Aflatoxin: Human Health, Veterinary, and Agricultural Significance, San Diego, USA.

37. Brown RL, Chen ZY, Cleveland TE, Russin JS (1999) Advances in the development of host resistance in corn to aflatoxin contamination by Aspergillus flavus. Phytopathology 89: 113-117.

38. Asia-Pacific Working Party on Prevention of Hepatocellular Carcinoma (2010) Prevention of hepatocellular carcinoma in the Asia-Pacific region: consensus statements. J Gastroenterol Hepatol 25: 657-663.

39. Anrade PD, De Mello MY, CAidas FJA (2012) Aflatoxins in food products consumed in Brazil: a preliminary dietary risk factor. Food Addit Contam Part A Chem Anal Control Expo Risk Assess.

40. Lavanchy D (2012) Viral hepatitis: globan goals for vaccination. J Clin Birol 55: 296-302

41. Key MC (2012) Epidemiology of chronic hepatitis B virus infection, hepatocellular carcinoma, and hepatitis B virus-induced hepatocellular carcinoma. Patho Biol (Paris) 58: 273-277.

42. Chang MH, Chen TH, Hsu HM, Wu TC, Kong MS, et al. (2005) Prevention of hepatocellular carcinoma by universal vaccination against hepatitis $B$ virus: the effect and problems. Clin Cancer Res 11: 7953-7957.

43. Chang MH, You SL, Chen CL (2009) Decreased insidence of hepatocellular carcinoma in hepatitis B vaccinees : A 20 year follow-up study. J Natl Cancer Inst 101: 1348-1355.

44. Montesano R (2011) Preventing primary liver cancer: the HBV vaccination project in the Gambia (West Africa). Environ Health 10: 56.

45. Viviani S, Carrieri P, Bah E, Hall AJ, Kirk GD, et al. (2008) The Gambia Hepatitis Intervention Study: 20 years into the Gambia Hepatitis Intervention Study: assessment of initial hypothesis and prospects for evaluation of protective effectiveness against liver cancer. Cancer Epidemiol Biomakers Prev 17: 3216 3223.

46. Luo Z, LI L, Ruan B (2012) Impact of the implementation of a vaccination strategy on hepatitis B virus infections in China over a 20 -year period. Int $J$ Infect Dis 16: 82-88.

47. Wild CP, Gong YY (2009) Mycotoxins and human disease: a largely ignored global health issue. Carcinogenesis 31: 71-82.

48. Kim BK, Han KH, Ahn SH (2011) Prevention of hepatocellular carcinoma in patients with chronic hepatitis B virus infection. Oncology 81: 41-49.

49. Tabor E (1991) Strongly supported features of the association between hepatitis $B$ virus and hepatocellular carcinoma. In: Etiology, Pathology and Treatment of Hepatocellular Carcinoma in North America (Tabor E, Bisulgi AM, Purcell RH, edition), The Woodlands, TX, USA.

50. Groopman JD, Kensler TW (2005) Role of metabolism and viruses in aflatoxininduced liver cancer. Toxicol Appl Pharmacol 206: 131-137.

51. Hoque A, Patt YZ, Yoffe B, Groopman JD, Greenblatt MS, et al. (1999) Does aflatoxin $B 1 \quad$ play a role in the etiology of hepatocellular carcinoma. Nutr Cancer 35: 27-33.

52. Yu, MC, Mack T, Hanisch R, Peters RL, Henderson BE, et al. (1983) Hepatitis, alcohol consumption, cigarette smoking, and hepatocellular carcinoma in Los Angeles. Cancer Res 43: 6077-6079.

53. Rogers AE, Conner MW (1976) Alcohol and cancer. Adv Exp Med Biol 206 473-495.

54. Nalpas B, Brechot C (1992) The role of hepatitis viruses in the genesis of hepatocellular carcinoma in alcoholic cirrhotics. Alcohol and cancer. CRC Press, Florida, USA.

55. Nalpas B, Pol S, Thepot V, Berthelot P, Brechot C (1995) Hepatocellular carcinoma in alcoholics. Alcohol 12: 117-120.
56. Arico S, Corrao G, Torchio P, Galatola G, Tabone M, et al. (1994) A strong negative association between alcohol consumption and risk of hepatocellular carcinoma in cirrhotic patients. Eur J Epidmiol 10: 251-258.

57. Maddrey WC (1995) Alcohol and the liver: an overview. Alcoholic liver disease. Pathology and pathogenesis. Edward Arnold, London.

58. Lee Fi (1966) Cirrhosis and hepatoma in alcoholics. Gut 7: 77-85.

59. Hislop WS, Masterton N, Bouchier IAD, Hopweed D (1982) Cirrhosis and primary liver cell carcinoma in Tayside: a five year study. Scottish Med J. 97 29-36.

60. Shibata A, Hirohata T, Toshima H, Tashiro H (1986) The role of drinking and cigarette smoking in the excess deaths from liver cancer. Jpn J Cancer Res 77: 287-295

61. Colombat M, Charlotte F, Ratziu V, Prynard T (2002) Portal lymphocytic infiltrate in alcoholic liver disease. Hum Pathol 33: 1170-1174.

62. Raynard B, Balian A, Gallik D, Capron F, Bedossa P, et al. (2002) Risk factor of fibrosis in alcohol-induced liver disease. Hepatol 35: 635-638.

63. Kiatpongsan S, Campos NG, Jane M (2012) Potential benefits of secondgeneration human papillomavirus vaccines. PLoS One 7: 48426.

64. Armstrong EP (2012) Prophylaxis of cervical cancer and related cervica disease: a review of the cost effectiveness of vaccination against ongogenic HPV types. J Manag Care Pharm 16: 217-230.

65. Laz TH, Rahman M, Berenson AB (2012) An update on human papillomavirus vaccine among 11-17 year old girls in the United States: National Health Interfiew Survey, 2010. Vaccine 30: 3534-3540.

66. Gonçalves DU, Proietti FA, Ribas JG, Araújo MG, Pinheiro SR, et al. (2010) Epidemiology, treatment, and prevention of human T-cell leukemia virus type 1-associated diseases. Clin Microbiol Rev 23: 577-589.

67. De The G (1995) Viruses and human cancers: challenges for preventive strategies. 1995. Environ Health Prespect 8: 269-273.

68. Secretan B, Straif K, Baan R, Grosse Y, El Ghissassi F, et al. (2009) A review of human carcinogens - part E: tobacco, areca nut, alcohol, coal smoke and salted fish. Lancet Oncol 10: 1033-1034.

69. Parkin DM (2011) Tobacco-attributable cancer burden in the UK in 2010. Brit J Cancer 105: 6-13.

70. Fenelon A, Preston SH (2012) Estimated smoking-attributable mortality in the United States. Demography 49: 797-818.

71. Dela Cruz CS, Tanoue LT, Matthay RA (2011) Lung cancer: epidemiology, etiology and prevention. Clin Chest Med 32: 605-644.

72. de Groot P, Munden RF (2012) Lung cancer epidemiology, risk factors, and prevention. Radiol Clin North Am 50: 863-876.

73. Thun M, Petro R, Boreham J, Lopez AD (2012) Stages of the cigarette epidemic on entering its second century. Rab Control 21: 96-101.

74. Su Delong (1979) Relationship of rate of liver cancer incidence and death to source of drinking water. Chinese Med J 92: 748-756. 